\title{
Vigilante Citizenship: Sovereign Practices and the Politics of Insult in Indonesia
}

\author{
Kari Telle \\ Senior Researcher, Chr. Michelsen Institute (CMI), Bergen \\ kari.telle@cmi.no
}

\begin{abstract}
This article examines the informal authority wielded by civilian security groups (pamswakarsa) on the island of Lombok. Taking as its point of departure the Balinese minority's plan to build a large Hindu temple in northern Lombok, the article shows how the project was thwarted by a combination of rumours, pamphlets, violence as well as legal obstacles from district and provincial authorities. Outlining how the campaign against the temple gained momentum, I suggest that rumours and documents issued by a security force claiming to represent the island's Muslim majority played an important role in preventing the realization of the temple. Discussing the 'conviviality' between non-state security groups and state officials in post-Suharto Lombok, I argue that civilian security groups exercise a form of vigilante citizenship.
\end{abstract}

Keywords

security groups, vigilantism, informal sovereigns, temple construction, Lombok

\section{Introduction}

In November 2007, Tuan Guru Haji (TGH) M. Sibawaihi Mutawalli, the spiritual leader of Amphibi, a Lombok-wide Islamic civilian security group, issued a written statement in response to plans to build a Hindu temple in northern Lombok. ${ }^{1}$ The statement opened by declaring Amphibi's support for the district head (bupati) of West Lombok, who some months earlier

${ }^{1}$ A first version of this article was presented at the panel 'Contesting the state: violence, identity and sovereign practices in Southeast Asia' at the ASEAS UK conference in September 2009. I am grateful to Lee Wilson and Laurens Bakker for inviting me to this panel and for their helpful comments on an earlier draft. I also wish to thank two anonymous reviewers of the Bijdragen for their highly insightful suggestions. 
had ordered the construction to be stopped in order to prevent conflict. ${ }^{2}$ The statement went on to observe, 'If the building of this temple proceeds, this means that the dignity and self-respect of the Muslim community in the province of West Nusa Tenggara is trampled on. ${ }^{3}$ Presenting the planned temple as a deliberate insult to the Muslim ummat, in whose name Amphibi claimed to be speaking, TGH M. Sibawaihi Mutawalli urged that all activities associated with the site, including religious ones, should be immediately halted. He also appealed to the government and the police to 'act firmly' (tindak tegas) against those who failed to comply with this instruction. The statement closed with a threat: 'Should the government and justice apparatus fail to take action, we in Pamswakarsa AMPHIBI NTB will have to get involved to stop all activities related to the construction of pura pesinggahan agung rinjani in Senaru village in the Bayan district of West Lombok, NTB,' followed by the phrase 'Allahu Akbar' (God is great), repeated three times. ${ }^{4}$ In keeping with bureaucratic practice, the list of recipients was appended to the statement that was signed by Amphibi's leader and stamped with their logo. The statement was never discussed in the official news media.

The past decade has witnessed significant changes in the complex relationship between state and society in Indonesia. Since the resignation of President Suharto in 1998 and the ensuing transition toward democracy and regional autonomy, known as reformasi, the political landscape on the island of Lombok has been characterized by a simultaneous pervasiveness and transformation of the state. While government institutions remain important, the state functions of governance, including the definition and enforcement of collectively binding decisions on members of society, by no means rest exclusively in formal state institutions. Rather, multiple social groups exercise public authority by imposing decisions of a public regulatory nature. These include a range of civilian security groups (pamswakarsa) organized along religious and/or ethnic lines. Seeking to reshape local and

\footnotetext{
2 Surat Bupati Lombok Barat, No. 454/26/KUM/27/2007, Perihal: Penghentian Pembangunan.

3 The Indonesian version reads: Jika pembangunan pura tersebut dilaksanakan berarti menginjak injak martabat dan harga diri ummat Islam NTB.

4 Capital letters, italics and underlined phrase as in the original. The name of the temple (pura) as listed in this statement is incorrect and instead it should be Pura Kahyangan Jagad Penataran Agung Gunung Rinjani.
} 
regional identities, these groups challenge the state's claims to sovereign power through the exercise of violence and the policing of territory.

This article aims to contribute to an understanding of contemporary Indonesian political dynamics by addressing the informal authority wielded by civilian security groups. ${ }^{5}$ Given the visible role that security groups have assumed in Lombok politics since the collapse of the New Order regime in 1998, the term 'informal' authority is somewhat inaccurate. These groups are perhaps better described as 'twilight institutions' (Lund 2006:686), which 'operate in the twilight between state and society, public and private.' By taking active roles in everyday policing and security management, they contribute to a further blurring of the boundary between public and private, licit and illicit. Most groups justify their existence by stressing alleged shortcomings of the state apparatus. In so doing they project the idea of a unitary state 'above' society, while claiming to act in lieu of this lapsed state (Abrams 1988). Yet the successful ways in which some groups have navigated the political landscape betray a keen awareness that the state, far from being a unitary subject capable of action, is non-unitary and fragmented (Aretxaga 2003; Klinken and Barker 2009). Institutional fragmentation, coupled with intense competition among state officials and candidates for public office, has yielded ample opportunities for security groups to pursue alliances with politicians, bureaucrats and members of the police. Such alliances embed the state-in-society (Migdal 2001) and embolden sectarian groups to portray themselves as defending 'public' interest, even as they enact their own law.

In this article I examine the controversy surrounding the Balinese minority's plans to build a large Hindu 'state' temple in a sparsely populated area of northern Lombok. These plans provoked hostile reactions from various quarters of Sasak society, including Amphibi, an Islamic crime-fighting organization (pamswakarsa) originating in Jerowaru, East Lombok. The project was thwarted by a combination of rumours, intimidation and violence, as well as legal obstacles from district and provincial authorities. This case, which generated much tension in Lombok Balinese circles, brings the centrality of violence in local politics into view. While violence

5 This article is based on nine months of fieldwork carried out between 2001 and 2011. For much of this time, I was based in Cakranegara, West Lombok, working mainly among Balinese. I also draw on insights gained from 15 months of fieldwork in Sasak communities in rural Central Lombok since 1994. 
is often seen as a breakdown of social order, I suggest that threats and violence have become almost routine ways of conducting politics on Lombok in the post-Suharto era. The decentralization and democratization process has spawned new forms of 'conviviality' (Mbembe 2001) between state officials and civilian security groups. One discernible dynamic is that security groups create 'issues' by spreading rumours and pamphlets, and threatening violence. In raising the spectre of violence, they count on state officials to discipline those who provoked the outrage in the first place. Such dynamics underscore that these groups exist 'on the frontiers-structural and/or cultural — of state power', as has been argued for vigilantism more generally (Abrahams 2007:423).

Rather than positing a sharp dualism with regard to the values and modus operandi of security groups and state agencies, I consider them to be enmeshed in one another (Das and Poole 2004:22). These groups are not 'outside' the law and the state as such, but appear more as 'a subcontracted, supplementary form of state power' (Sidel 2006:140). Their capacity for violence is variously deployed or disavowed as excessive depending on political circumstances, while their 'twilight' character renders them virtually immune to prosecution. As citizenship has been implemented under the double logic of democracy and security, albeit biased toward the latter, civilian security groups effectively exercise a form of vigilante citizenship. An unfortunate by-product of this political rationality centred on security and public order is that it becomes difficult to voice real political grievances.

\section{Religion, Security, and Sovereign Practices}

Located just east of Bali, Lombok joins its neighbour island Sumbawa to form the Indonesian province of West Nusa Tenggara. Lombok has an ethnically and religiously diverse population of some 3.2 million inhabitants. The Sasak, most of whom are Muslims, constitute about 92 per cent of the population. Besides longstanding Chinese and Arab communities, there is a sizable Balinese and Javanese presence. Balinese Hindus, numbering approximately 150,000 people, form the largest ethnic and religious minority. They have a strong identity as Lombok Balinese, having lived there for many generations and, in some cases, inter-married with the Sasak (Harnish 2006; Hägerdal 2001). Their deep attachment to the island is expressed 
in rituals, temple festivals and religious architecture. Like other religious minorities in Indonesia, the Lombok Balinese have grown more concerned about their status as a minority in the post-Suharto period. Their anxiety has been further increased by the growing use of exclusivist 'sons of the soil/region' (putera daerah) discourses combined with militant forms of Islamic mobilization.

Religion has returned to public life and politics on Lombok with a vengeance in the post-Suharto era. One significant new development has been the rise of a plethora of faith-based security groups dedicated to fighting crime, enforcing justice and offering 'protection'. This coupling of religion and security concerns is partly an effect of the religious policies adopted by the New Order state, which heightened the salience of religion as an identity-marker for Indonesians. As Hefner (2000:59) notes: 'Regime strategists looked to organized religion as a ground for public morality, a shield against Western liberalism, and an antidote to communism'. All citizens were required to adhere to one of five officially recognized religions, and it was religion (agama) rather than other identity-markers that was printed on people's identity cards. The official endorsements of depoliticized forms of religion, expressed through mandatory religious education, conveyed the idea that 'agama is progressive (maju) and a requisite of good citizenship' (Kipp and Rogers 1987:23). While Confucianism has since been added to the list of officially approved religions, the current regime is also taking strong measures to regulate religion. The 2010 decision by Indonesia's Constitutional Court to uphold the controversial 1965 Blasphemy Law underscores the continuity between the New Order's conflation of religious and political dissidence and the current construction of 'heresy' as a threat to national security and public order (Olle 2009). ${ }^{6}$

The proliferation of faith-based security groups has also been enabled by changes in the organization of security. These changes are not simply the result of Indonesia's transition from military-dominated rule to neoliberal democracy, but reflect global changes in the governance of security

6 On the judicial review of the Blasphemy Law in the Constitutional Court, see Crouch 2012. For Lombok's Ahmadiyah community the situation has become very difficult, especially since 2005, when Majelis Ulama Islam (MUI) issued a series of fatwa that deemed Ahmadiyah a 'deviant' sect. Following a series of attacks on mosques and homes, they have taken refuge in government-provided facilities in Mataram, a situation that has lasted for years, see Budiwanti 2009 and Kingsley 2012. 
associated with deregulation, decentralization and the 'outsourcing' of services to the market and to volunteers (Bubandt 2005; Sen and Pratten 2007; Telle 2010). In 1999 the police achieved autonomy from the military, which had lost its former near-monopoly on the 'securitization' (Wæver 1995) of society. Under the New Order, the armed forces had a 'dual mandate' to defend the state and to maintain stability by guiding the development of society. The myth propagated by the regime was that the nation had fallen prey to disorder but was rescued by Suharto, the 'Father of Development' (Bapak Pembangunan), who provided 'safety' and 'order' and put the nation on the road to modernization. The violence committed by the regime remained unmentionable, especially the 1965-66 massacres of alleged Communists (Zurbuchen 2005), yet it was an open secret that the armed forces and the police cultivated profitable relationships with gangs. This blending of crime and authority has led some scholars to suggest that the regime operated like a criminal gang, normalizing violence and extortion as state practice (Lindsey 2001; Schulte Nordholt 2002). ${ }^{7}$ The regime routinely reminded citizens of the threat posed by internal enemies, be they political or criminal, cultivating a sense of paranoia (Siegel 1998). Taking part in the state-sponsored system of neighbourhood watches was seen as a masculine duty and an expression of a reified Indonesian culture based on mutual assistance and co-operation. ${ }^{8}$ This system had, as Barker (2007:89) has pointed out, several advantages for the regime: it cost the government very little, it facilitated a degree of state control over local security structures and 'it created a citizenry that thought and acted like police'.

What happened in early reformasi-era Lombok is that 'everyone' felt entitled to be a policeman. Signs of this kind of 'free-for-all sovereignty' (Day 2007:9) emerged during the last year of the New Order regime when the Asian economic crisis was felt in rising prices, unemployment and a wave of violent burglaries across the island. ${ }^{9}$ This growth of organized

7 In his intriguing critique of scholarly approaches to power in Indonesia, Beatty (2012:177) argues that an 'emerging picture of the government as criminal—not merely venal and violent but illegitimate-undermines the very idea of cultural hegemony that has been scholarly orthodoxy since Anderson'.

8 For an account of neighbourhood security systems on Java under the New Order, see Barker 1999.

9 According to Kristiansen 2003, the number of criminal cases registered in civil courts doubled between 1997 and 1998. Around this time, many communities stepped up secu- 
banditry occurred in an atmosphere of widespread cynicism regarding the interest of the police and the justice system in catching and prosecuting lawbreakers, and so popular crime-fighting efforts mushroomed. Most efforts took the form of neighbourhood watches, but some groups quickly transformed into supra-local militias headed by religious leaders with ties to high-level politicians. As an ICG report (2003:1) observed, "The sad fact is that in this post-Suharto era, the largest "civilian" organization on Lombok is a Pamswakarsa [self-reliant security corps].' The organization referred to is Amphibi, which in 1999, just four months after its formation, boasted of having some 200000 registered members. Although this figure may have been deliberately inflated, the existence of such massive organizations, whose members patrolled neighbourhoods, and tracked down, disciplined and sometimes killed alleged criminals, reveals that a vigilant citizenry had indeed been created (Telle 2010). Looking for alternatives to the discredited New Order security apparatus, many politicians, bureaucrats and academics on Lombok initially welcomed civilian crime-fighting groups as 'a new form of 'people's power' capable of taking care of security concerns' (MacDougall 2007:287). ${ }^{10}$ An aura of masculine prowess surrounded the men who, donning uniforms and carrying mobile phones, signed up and paid hefty membership fees to 'develop' the island by cleaning out crime.

Although sovereignty has historically been identified as a privilege of state institutions, the rise of anti-crime militias performing the state functions of everyday policing and criminal justice makes it clear that the state is not the only sovereign power on Lombok. The situation is more like a 'horizontally woven tapestry of partial sovereignties' (Comaroff and Comaroff 2006:35) with overlapping and competing logics of violence and territoriality. To make sense of local political dynamics, I therefore approach sovereign power not as a property of established institutions, but as a practice that must be performed on a continual basis. This approach is inspired by Hansen and Stepputat's (2005:3) approach to sovereign power as an always 'tentative and unstable project whose efficacy and legitimacy

rity measures, not least because they had little or no faith in the police or official justice apparatus.

10 In an interview with TGH Muchlis Ibrahim, an Islamic leader from Kediri and head of the government-appointed Forum Pam Swakarsa, in July 2001, he estimated that there were 68 registered groups in West Nusa Tenggara. He also assumed that many similar groups had not been registered. 
depend on repeated performances of violence and a 'will to rule"'. Seeking to disentangle the notion of sovereignty from the state, they argue that sovereign power exists in overlapping and competing forms. In their approach, inspired by Carl Schmitt (1976) and Giorgio Agamben (1998), the focus is on the 'precarious construction and maintenance of localized sovereign power through exercise of actual or "spectral" violence-transmitted through rumours, tales, and reputations' (Hansen and Stepputat 2005:3-4).

An emphasis on the performative aspect of sovereignty is a useful starting point in examining the authority wielded by civilian security groups in contemporary Lombok. Despite important differences between these groups in terms of size, structure, ideologies and political ambitions, their authority is founded on their potential for violence (MacDougall 2007; Telle 2010). There is no doubt that Amphibi, whose members like to brag that they belong to the largest pamswakarsa force in Indonesia, operates through violence or the threat of violence. But as the statement quoted in the introduction indicates, its authority is also constituted by way of different registers. Like other Lombok-based security groups, Amphibi has appropriated several 'languages of stateness' (Hansen and Stepputat 2001:5). Considerable attention has been paid to fashioning the artefacts of modern state power, such as laminated membership cards, seals, stamps and military-inspired uniforms. Amphibi's organizational structure mimics that of state institutions, with separate departments for security, law, proselytizing ( $\left.d a^{\prime} w a h\right)$, communication and welfare. Amphibi's authority, I will argue, does not simply rest on its capacity to exercise violence, but is asserted through its astute ability to speak and act like a sovereign entity. Were it not for Amphibi's ability to communicate by using multiple registers, including rumours, 'open letters' and public statements, it is unlikely that it would have become such an important player in local politics.

\section{Conspicuous Construction, Rioting, and the Politics of Insult}

While most security groups initially mobilized around the issue of 'crime,' which was seen as rampant around the time the New Order collapsed, it soon became apparent that some groups embraced a broader, if somewhat diffuse, agenda protecting the 'rights' and 'interests' of their respective religious communities. This pattern of militarization along religious lines occurred in a climate of fear, in which religious 'others' were portrayed as 
a threat to the self (Telle 2009a and 2010). Religious buildings and sacred sites, being highly charged sites of communal and religious identities, emerged as key loci where these struggles were played out. In this article, I am especially interested in the politics of insult, whereby efforts by religious minorities to build houses of worship are viewed with suspicion and taken as an affront to the religious sensibilities of the island's Muslim majority. In the case of the local Balinese initiative to build a large Hindu temple in northern Lombok, the island's religious identity and provincial politics were also at stake.

A few words about the anti-Christian rioting that began on January 17 , 2000 are in order here, because this dramatic event has cast a long shadow of suspicion over inter-religious relations. The riot began in Mataram, the provincial capital, immediately after an Islamic rally (tabligh akbar) held in support of Muslim victims of the violence in Maluku in eastern Indonesia, where ethno-religious clashes had occurred in January 1999. Drawing close to 6,00o participants, the rally was one in a series organized in different parts of Indonesia to express sympathy and raise money for Muslims in Maluku. Protestant and Catholic churches were the main targets of the riot, but houses and shops belonging to Christians - often, but by no means exclusively, of Sino-Indonesian descent-were also destroyed as their owners fled the island or sought refuge in military installations. The rioting spread rapidly from the urban areas of Mataram, Ampenan and Cakranegara to the tourist areas along the coast and into the hinterland of west and north Lombok, leaving behind a trail of burned and damaged buildings. ${ }^{11}$ Avonius (2004:71-2), whose fieldwork coincided with the rioting, found that many buildings were marked with insulting or threatening graffiti, a practice that in turn prompted people to mark façades of homes and businesses with quotes from the Qur'an to convey that the place was Muslim-owned.

Despite the seemingly spontaneous nature of the violence, the Lombok riots followed a familiar script involving the dissemination of provocative leaflets and VCDs depicting violence allegedly perpetrated against mosques and Muslims in Maluku. In the week before the rally, an open

${ }^{11}$ Official records report seven deaths and 54 severely injured, but eyewitness reports suggest that the number of casualties was higher. Several rioters were shot dead by Indonesian security forces, who followed instructions, issued after two days of rioting, to 'shoot on sight'. 
letter (surat terbuka) addressed to local Christians was put up in the provincial capital. ${ }^{12}$ The letter demanded that Christians should issue a written statement condemning the atrocities occurring in Maluku within 48 hours or face dire consequences. The letter was signed by members of the tabligh akbar committee, including the local leader of Persaudaraan Pekerja Muslim Indonesia (PPMI), an Islamic trade union, and Amphibi's founder, TGH M. Sibawaihi Mutawalli. Spokespersons for the latter later admitted that some members joined the rioting, but said that they acted on their own (Avonius 2004:66-72). Following the riot some efforts were taken to prosecute the instigators, and state-sponsored reconciliation initiatives sought to bring religious leaders from different faiths together. The effectiveness of these reconciliation initiatives is questionable, in my view. More significantly, state officials have kept the memory of the rioting alive by being quick to remind citizens of the need to avoid further violence, as this would have an adverse effect on the island's economy and tourism revenue.

The memory of the riots has also been kept alive by security groups operating through a combination of violence, threats conveyed through rumours and carefully crafted 'public' statements. As an instrument of instigation, the open letter not only caused fear among Christians but probably helped to prepare the ground for the rioting. Although the open letter made no mention of local Balinese, in the tense post-riot climate it served to confirm Balinese fears that the riot was part of a broader agenda of Islamization that would seriously jeopardize the position of Indonesia's religious minorities (Telle 2009a and 2011). These fears were renewed in 2007 by the harshly worded Amphibi statement denouncing the planned Hindu temple in northern Lombok. This statement drew some of its narrative efficacy from its similarity with the open letter that ushered in the January 2000 rioting. This intertextual dimension is key to understanding how the document, originally distributed to particular recipients and organizations, was read. Amphibi's practice of issuing warnings and ultimatums prior to violent confrontations ensured that, by 2007 , both state officials and Balinese involved with the contested temple were compelled to take the threat seriously, an issue I will return to shortly.

12 Besides the signed open letter, anonymous leaflets were also circulated in early January 2000. As MacDougall (2007:299) notes, 'a fake Christian missionary book was distributed ending with the phrase, "all Muslims must be exterminated". It was made to look as if Christians had made the book.' 
The situation on Lombok was relatively calm in 2005 when members of the Balinese community began planning to construct a temple, Pura Kahyangan Jagad Penataran Agung Gunung Rinjani, in the small village of Senaru at the base of the Rinjani volcano. Mount Rinjani, the impressive mountain towering over northern Lombok, has great cosmological significance for both Sasak and Balinese, and the latter regularly perform sacrifices on the shore of the crater-lake Segara Anak and use the water in various rituals. When Balinese from the Karangasem area settled on Lombok in the eighteenth century, they adapted to the new island by investing Rinjani with many of the qualities of the great Mount Agung in Bali. Rinjani became the focal centre, the abode of the divine ancestors and the home of Batara Gunung Rinjani, the divinity whose shrine is found in every major temple on the island (Harnish 2006:26). A common metaphor is that Mount Rinjani 'holds' (megang) Lombok, just like Mount Agung 'holds' Bali.

Mount Rinjani's close connection to other sacred mountains is indeed the major theme in the 40-page proposal that the temple committee put together to attract interest and support. The proposal, written in Indonesian with Balinese sections, opened by noting Rinjani's potent magical and sacred qualities, and underlined the importance of acknowledging these powers. It also pointed out that ancients texts, notably the Purana Hyang Pasupati, refer to Rinjani, Bali's Mount Agung and Mount Semeru on the island of Java as 'siblings' which were formed from parts of the great Mahameru mountain in India. The planned temple was thus placed within a spiritual landscape spanning Lombok, Bali and Java, and reaching all the way to India, which Indonesian Hindus increasingly consider as their spiritual homeland (Ramstedt 2004). ${ }^{13}$ Having established Rinjani's cosmological significance, the proposal writers noted that the existing temple, built in the early 1990s, is small and relatively unknown among Hindus on Lombok. Though classified as a 'world' temple (Pura Kahyangan Jagad), they argued that the temple is inappropriate for a place of such great spiritual calibre. Given Rinjani's sacred significance, the new temple would not merely be important to local Hindus but would be of great importance for Hindus throughout Indonesia and beyond.

The proposal left no doubt that the new temple was intended to put Lombok on the Hindu religious map. Its trans-local orientation was

13 For elaboration of the concept of 'spiritual landscape', see Allerton 2009. 
evident in the modern, distinctly Balinese design of the planned temple, as opposed to the classic Karangasem style found in older temples on Lombok. Besides a trend towards greater uniformity, contemporary temple architecture makes much use of concrete, and a monumental style with large statues and adornments is prefered (Hauser-Schäublin 1997). The planned temple was not meant to simply cater to the needs of local Hindus but designed to attract visitors from afar. As a member of Bayu Mandala, a Balinese pamswakarsa group in Cakranegara, told me in September 2006, 'The Rinjani temple will become a "tourist attraction" (obyek wisata).' Organized pilgrimage tours combining religious devotion with leisure are becoming increasingly popular among middle-class Hindus in Indonesia. Growing wealth and improved transportation make inter-island visits to famous temples feasible. Politicians and candidates for office are eager to be patrons of prestigious projects, such as the 'conspicuous construction' (Thomas 1998) of temples. Supporting the renovation or construction of temples is a way to demonstrate economic success and religious commitment, both of which may be important to secure political office, a process Hauser-Schäublin (2011) aptly terms 'spiritualized politics'. These broader trends were reflected in the impressive list of supporters named in the glossy proposal, complete with professionally made drawings and foldouts of the main shrines. To solicit funds for the costly project, estimated at close to 9 billion rupiah, the committee made several trips to Bali and secured financial support from well-to-do Balinese and members of the political elite, including Dewa Made Beratha (1998-2003), the former governor, Made Mangku Pastika, Bali's current governor, and Satria Naradha, the owner of the influential Bali Post media group. The plan also gained support from prominent Hindus in Jakarta and was approved by Parisada Hindu Dharma Indonesia (PHDI), the national body of Hindu affairs that works to codify religious practice. ${ }^{14}$

In their meetings with village authorities and local residents in Senaru, the temple committee emphasized that the temple would benefit people irrespective of their religious affiliation. Besides a paved road and electricity, they stressed that the big temple would inject much-needed cash into

14 In 1958, the Balinese version of Hinduism (Agama Hindu Bali) was elevated to the status of a national religion recognized and supported by the state. In the same year Bali became a separate province, while Lombok and Sumbawa formed the new province of Nusa Tenggara Barat (NTB). 
the area, since the visitors would have to park their vehicles, buy food and drink, and possibly stay overnight. According to a building contractor who took part in these meetings, the plan, which involved the buying of land, was initially well received not only among Balinese but also by Sasak villagers. Noting that several meetings were accompanied by good food, rice wine as well palm liquor, he attributed the success of these negotiations to the fact that Balinese and many Sasak in the area enjoy the same drinks or 'social lubricants'. ${ }^{15}$ But this harmonious situation, if it ever existed, certainly did not last. As Gdé Mandia, a former head of the provincial chapter of PHDI, explained to me in 2006, the plan encountered hostile reactions from influential Islamic preachers and the sub-district head. Over time, the village headman also turned sceptical. In Mandia's view this hostility arose from two interrelated factors: a misunderstanding about the nature of Hinduism, and a form of jealousy (cemburu sosial). He explained, 'Some local figures, especially Muslim religious leaders (tuan guru), seem to believe that the Rinjani temple [will be] built in order to attract converts. But everyone knows that Hinduism, unlike Islam, is not a proselytizing religion.' ${ }^{16}$ In mentioning jealousy, Mandia referred to speculations that the temple was lavishly financed with money from 'outside' sources, including foreign ones. This interpretation highlights a recurring theme in religious politics in post-reformasi Lombok, where initiatives by religious minorities to build houses of worship quickly raise suspicion of surreptitious proselytization (Budiwanti 2009; Telle forthcoming). Suspicion and resentment are likely to increase when such construction activity involves 'outside' wealth, which suggests a larger campaign.

\section{Rumours, Documents, and 'Legibility'}

As these plans came to the attention of Muslim religious leaders, popularly known as tuan guru, questions were raised about the rationale of building a big temple in a predominantly Muslim area. This inspired a number of

15 Interviews conducted in Cakranegara, September 2006. Bayan is one area of Lombok where a non-standard variety of Islam known as Wetu Telu has held sway despite ongoing proselytizing efforts. While orthodox Muslims will not touch alcohol, there is a long Sasak tradition of making locally produced alcoholic beverages (arak, tuaq, poteng).

16 Interview conducted in Cakranegara, 17 September 2006. 
rumours, which centred on the anomaly of building a large temple on Lombok, also known as the 'island of a thousand mosques' (pulau seribu mesjid). One persistent rumour alleged that the Rinjani temple was designed to be the largest Hindu complex in Southeast Asia. Several of my Sasak friends, who are neither militant nor particularly observant Muslims, assumed that the temple was to be the largest in Asia, an ambition they considered improper. The mobilizing role of rumour in the context of sectarian violence has been stressed in recent scholarship (Hefner 2000; Sidel 2006; Spyer 2006). The interplay of rumours and pamphlets, a staple ingredient in sectarian conflicts in Indonesia, deserves further scrutiny. In a study of the thriving pamphlet politics accompanying the Maluku wars, Bubandt (2008) has shown how inflammatory pamphlets tapped into a culture of rumour, contributing to the creation of the paranoid atmosphere in which the violence occurred. Stressing the complicity between rumour and writing, Bubandt (2008:795) suggests that little attention has been paid to how 'the authority of writing may boost the affectivity of rumour'. This suggestion is relevant for understanding dynamics of instigation on Lombok, where rumours circulate alongside open letters and other documents that straddle the sometimes blurred line between official and unofficial discourse. I will now show how rumours and documents operate together as key elements in the affective politics of instigation.

By the time Amphibi's leader threatened to mobilize his large security force to stop all activities at the controversial temple site, all construction activity had already ceased. The project had turned into a major political issue, and considerable political pressure had been put on the temple committee, Hindu organizations and Balinese associations to cancel the plans in order to prevent the situation escalating into open conflict. Although the temple committee had grown used to receiving threatening anonymous phone calls and SMS messages, they put a stop to construction work in October 2007 after the heavy machinery for preparing the site was burned and destroyed. According to a local temple priest (pemangku) who witnessed this incident, the appearance of several hundred men in the village caused the frightened Balinese residents to seek refuge in the old temple. ${ }^{17}$ Over the next few weeks, a number of Islamic leaders from different parts of the island visited the village, letting it be known that while Hindus were

17 Interviews conducted in Senaru, June 2011. 
free to build temples on neighbouring Bali this would not be tolerated on Lombok. Following this incident, the local government put up a notice forbidding activities at the temple site.

As noted in the introduction, the Amphibi statement opened by expressing support for the district head's rejection of the planned temple. ${ }^{18}$ As such, the statement speaks directly to the broader discursive domain, in this case the 'official' domain of political communication. Under point za we find what appears to be Amphibi's main rationale for opposing the Rinjani temple: 'If the building of this temple proceeds, this means that the dignity and self-respect of the Islamic community in the province of West Nusa Tenggara is trampled on.' By describing the temple as an insult to Muslims in the province, the statement implicitly lent substance to the rumour that the temple would dwarf other temples in Southeast Asia or Asia, a rumour that was uncritically reproduced in the local press and picked up in official reports about the case. Operating in a discursive universe where official and unofficial discourses interpenetrate (see also Bubandt 2008:792-94), this document invoked a religious imagery of desecration to incite resentment. The harsh image of 'trampling on' the dignity of the Muslim community is reminiscent of the images of desecration deployed in contexts of sectarian strife, where revenge is justified by accounts of how the opposing party mock or attack religious objects. However, here it is the mere presence of a temple that is portrayed as a form of humiliation. In this document, Amphibi portrays itself as the genuine defender of the Muslim ummat, ever ready to step in should the police and the state apparatus prove incapable. Indeed, the statement ends by threatening that should the authorities fail to take action, the pamswakarsa AMPHIBI NTB would be forced to get involved (turun tangan) in order to stop all activities related to the construction of the temple. ${ }^{19}$ As if to leave no doubt that Amphibi keeps its word, these lines are underlined. The list of recipients appended to the statement included the President of Indonesia, the armed forces and the Minister of Religion, as well as the Jakarta-based vigilante group Front Pembela Islam (FPI). ${ }^{20}$ Besides the Governor, the armed forces, and the police, the list of

18 The district head (bupati) in West Lombok at the time was Haji Iskandar. Iskandar was embroiled in scandals related to polygamy and the mismanagement of government funds, see also Avonius 2004.

19 See the introduction and note 4 for the wording of this statement.

20 On Front Pembela Islam (FBI) and its Islamic 'mission,' see Wilson 2009 and 2012. 
recipients on Lombok included Dharma Wisesa, a Hindu Balinese security force organized in 2000 (Telle 2009a and 2011). Some of the recipients photocopied the statement, which they then disseminated via informal channels, making Amphibi's threat known to a wider circle of people.

It is partly by issuing such 'official' statements that Amphibi has constituted itself as an informal sovereign and works to maintain its position as a key player in Lombok politics. Amphibi has mastered bureaucratic forms of communication, including the production and circulation of documents, perhaps more successfully than other security groups on Lombok. By 'speaking like a state', to paraphrase James Scott (1998), Amphibi leaders not only borrow authority from the state but strive to make themselves legible to state officials and politicians. 'Legibility,' Scott writes, 'is a condition of manipulation' (Scott 1998:183), as it is only through the invention of units that are visible that modern states can actively intervene in society. Amphibi and similar organizations, however, have used legibility as a strategy for engaging the state, gaining respectability and recognition as well as access to funds and 'security'-related projects. ${ }^{21}$ At its simplest, this process entails drawing up the statutes (anggaran dasar) and rules of association (anggaran rumah tangga) and getting these approved by a lawyer or notary. As a registered foundation (yayasan), Amphibi is in a position to offer security services to and solicit support from municipal, sub-district, district and provincial state officials, who, over the past decade or so, have been eager to support enterprises carried out in the name of 'security', especially when such initiatives have been run by 'traditional' or religious leaders (Telle 2009a). Prior to elections, heads of civilian security groups are courted by candidates for political office, who promise funds in exchange for votes and political support. In turn, patrons may expect groups to provide security-related services or to demonstrate popular support in connection with controversial projects. In the run-up to the 2008 NTB gubernatorial elections, the small town of Jerowaru, where Amphibi is based, hosted several of the candidates. ${ }^{22}$ Such unstable alliances and

21 In Seeing like a state (Scott 1998), Scott relies heavily on a visual metaphor in his analysis of modern administrative technologies. But figuring the state as an observer can, as Hull 2012:166 notes, 'lead[s] one to assume the unity of state representations rather than demonstrate how such unity is achieved (or not) through coordination in practice'.

22 In connection with the 2008 gubernatorial elections there were concerns that pamswakarsa groups could cause violence. Kingsley 2012 provides an interesting case study of 
networks of patronage are an important dimension of local politics in the context of highly competitive electoral politics, a pattern also seen in other parts of Indonesia (Hadiz 2010; Wilson 2010). As political dynamics change, the heads of security groups, some of whom aspire to political office and a seat in Parliament themselves, have become more confident. Mindful of the numerical strength of their sprawling organizations, these men are not content to be bossed around by traditional political elites, but are 'testing the boundaries of the state' (Wilson 2012) and articulating claims based on populist, communal and/or religious identities.

The Amphibi document reveals a mentality akin to what Arjun Appadurai (2006:51-3) calls 'predatory identities,' identities whose construction and mobilization require the extinction of other, proximate social categories, defined as threats to the very existence of a given group. According to Appadurai, 'predatory identities' tend to emerge out of pairs of identities which have long histories of close contact, mixture and some degree of mutual stereotyping. Identities turn predatory when a group comes to see itself as a 'threatened majority'. The historical relationship between Balinese and Sasak partly explains the suspicion that came about because of the initiative to build a large temple with money from 'outside' sources. Between 1740 and 1894, a branch of the Karangasem dynasty acquired control over Lombok and a Balinese population settled in the western part of the island. Balinese claimed political and ritual superiority and Sasak were placed in inferior administrative positions. But Sasak joined Balinese irrigation societies, participated in temple festivals and worshipped at their shrines. Some of these practices continue to the present day (Harnish 2006; Telle 2009c). The situation was very different in east Lombok, where the Balinese never consolidated their power and Islam became a marker of Sasak identity as distinct from the Balinese rulers. Members of the Naqsyabandiyah Sufi order, which condemned the Balinese overlords as infidels, played important roles in the rebellion that broke out in 1891. In 1894, the Dutch army and Sasak from east and central Lombok defeated the Balinese and their allies, and Lombok passed under Dutch rule. There is thus a strong religious dimension to what many Sasak nowadays see as a long and humiliating history of rule by 'outsiders' (McVey 1995). Since the late

the conflict-management strategy and the role of Islamic leaders (tuan guru) in connection with the NTB gubernatorial elections. 
nineteenth century, Islamic reformers have striven to purify Muslim practices, and they have been inclined to see local forms of Islam centred on the propitiation of ancestors and sacred sites as 'a kind of perverted Hinduism' (Cederroth 1999:10). To pave the way for a 'genuine' Sasak culture based on Islamic principles, ritual practices and performing arts that appear to be of Balinese origin have often been banned or discouraged. The area of Lombok where the Rinjani temple was to be built is among the areas where a localized form of Islam, known as Wetu Telu has long held sway. It is also an area where many Sasak in the late 196os, following the reprisals against communists, converted to Hinduism or Buddhism rather than embrace a more orthodox form of Islam (Cederroth 1999). This long and complex history helps explain why some groups deemed the temple an insult and called for a militant resolve to prevent its realization.

The most recurring theme in the campaign against the planned temple centred on the anomaly of building a large temple on an island that has a Muslim majority population. As an Amphibi leader from Ampenan explained in June 2009, 'On Lombok, the majority of the population are Muslims, whose symbol is the mosque. Lombok is known as the "island of a thousand mosques". Hence, it is clearly not right to build an international temple (pura internasional) in a place where the majority of the population are Muslims. This is something that we should all [Lombok residents] be aware of and respect.' He also assured me that if the Muslim minority on Bali had tried to build a large mosque on 'the island of the gods' (pulau dewata), the initiative would surely have fuelled equally intense resentment. A similar view was articulated by TGH Sofwan Hakim, ${ }^{23}$ an influential Islamic leader who heads the Nurul Hakim pesantren in Kediri West Lombok and has long had a weekly column in the Lombok Post. He noted, 'The temple in Kebaloan is in a good condition. But then somebody came up with the plan to build the largest temple in Southeast Asia. If this had happened, it would have destroyed the reputation of Lombok as "the island of a thousand mosques", hence people got upset. My opinion is that it is "not fitting" (tidak cocok) to build here. People should also be professional. Muslims on

${ }^{23}$ As the head of the Forum Kerjasama Silaturahmi Pondok Pesantren, NTB, TGH Guru Sofwan Hakim is in regular contact with Muslim leaders who run Islamic boarding schools. During our interview in June 2011, he confirmed that he involved this network in connection with the controversial Rinjani temple. Over the past 25 years, Sofwan Hakim has sponsored and supervised a network of Islamic teachers on their dakwah mission in the Bayan area, and he initially learned about the construction plan from these teachers. 
Lombok are actually very tolerant. There are several big temple complexes, in Lingsar, Suranadi and Cakranegara, and we just let them be. But we hope that they do not try building temples in a place where there are not many residents, and those who want to build should think about not hurting the feelings of other people. That does not mean we are not tolerant. It means they should think about keeping the situation calm and harmonious. In Kebaloan, you know, there is already a temple, which is appropriate to the needs of local Hindus. But now they want to bring Hindus from India, from Jakarta and other far-off places. We also have information from Bali that Muslims have difficulties building mosques. For instance, in Ubud it has been very difficult. Here on Lombok we value Balinese people, but they also need to respect the feelings of people from other religious communities.' Though it is difficult to assess how plans to build a mega mosque in Bali would have fared, my sources are right in pointing out that tensions over places of worship of minority groups is by no means unique to Lombok. On Bali, concerns have been raised about the influx of Muslim immigrants and 'Balinese culture is also,' according to Schulte Nordholt (2007:57), 'increasingly presented as exclusively Hindu.'

\section{Acting like a State}

Another salient aspect of how the campaign against the planned Rinjani temple was carried out involves the legal issue of permits. In 2006, the Minister of Religion and the Minister of Internal Affairs issued a Joint Ministerial Regulation on Places of Worship No. 8 \& 9. The Regulation stipulates the conditions under which houses of worship may be built or renovated in Indonesia, and introduced a more comprehensive framework for the issuing of permits than the 1969 decree it replaced. This is not the place to detail the events that prompted the revision of the 1969 decree, but one criticism maintained that it discriminated against minority religions by giving considerable power to local authorities to determine whether or not a house of worship could be built (Crouch 2007). The complex administrative procedures also meant it could take a very long time for religious minorities to obtain a permit, if at all. ${ }^{24}$

24 Since 2005, the old Decree has also been in conflict with Indonesia's religious freedom obligations under the Constitution and national laws. In October 2005, Indonesia ratified the International Covenant on Economic, Social and Cultural Rights (ICESCR) and the 
Some have raised concerns about several articles in the new Regulation, which is considerably more detailed than the old decree (Crouch 2010). For instance, Article 13/1 states that the construction of a place of worship must be based on a 'real need', yet leaves it unclear who is to make the final decision about such needs (Ropi 2007). Moreover, the group wishing to build a place of worship must obtain the signatures and copies of the identity cards of at least go members of their own congregation and at least 60 local residents of another religion, and this list has to be approved by the village head (Article 14/2). The '9o/6o requirement' is problematic for several reasons, not least by linking the granting of a permit to numbers and residence. Crouch (2007:116) argues, 'By passing the New Regulation, the state has made it more difficult for religious minorities to obtain a permit to build a place of worship than in the past.' While the new Regulation has become politically important on Lombok, my view is that it has not served to protect the interests of religious minorities.

Although the new Regulation came into effect after the temple committee began to prepare for the Rinjani temple, this regulation proved a major obstacle to its realization. Anticipating that a request for a construction permit might be denied, the committee initially defined the project as a renovation of an existing temple. Considering that the temple was to be built at a significant distance from the existing one, they clearly stretched the definition of renovation. When the committee eventually applied for a construction permit, the issue had grown so 'hot' (panas) that the application was rejected. District and provincial authorities stressed the need to avoid sectarian conflict, and it therefore mattered little that the committee had obtained the required number of signatures from residents supporting the project. Groups opposed to the temple were also keen to expose the fact that the committee had failed to apply for a permit, and this alleged failure to comply with the 'law' caused resentment. Tellingly, Amphibi, whose reputation was built through extrajudicial violence and aggressive shows of force, was among those who called on state officials to ensure that the law was respected. Rather than seeing this as a contradiction, I interpret this oscillation between playing the legal card and engaging in violence as a key dimension of the performance of sovereignty. If we follow Carl Schmitt's

International Covenant on Civil and Political Rights (ICCPR). These were implemented under Law 11/2005 and 12/2005 respectively, see Crouch 2007. 
(1976) idea that sovereignty originates in the 'exception' (Ausnahme), or in the capacity to suspend the law, and is constituted in the capacity for excessive violence, Amphibi's oscillation between upholding and suspending the law is arguably integral to its demonstration of sovereign power.

Opposition to the Rinjani temple also involved efforts to curb ritual activities at the temple site, and these efforts reveal an intriguing interplay of state and non-state actors. Again it is important to recognize how the mobilizing role of rumour together with threats of violent mass mobilization by civilian security groups shapes local politics in contemporary Lombok. By October 2007 it seemed highly unlikely that the temple would be built, yet members of the Hindu Balinese community had long prepared for a purification ritual at the site. According to my Balinese sources, the purpose of the ritual, known as Upacara Yadnya Karya Agung Bhuana Kertih, was to restore the world to a state of harmonious balance and to safeguard the planned temple and those associated with it. Preparations had been going on for months and in September several Hindu priests (pedanda) accompanied by about 9o people travelled to collect holy water (tirta) from the 'mother' temple Besakih in Bali and from Pura Mandargiri in east Java. As these preparations became known, rumours began circulating that the real purpose of the ritual was to put down the first stone of the temple, implying that the organizers intended to defy the government's refusal to grant a permit. It was also rumoured that huge numbers of participants from all over Indonesia and abroad, notably India and America, had been invited to attend the ceremony.

The decisions of various government bodies to interfere with the planning of the purification ritual appear to have been made in direct response to these rumours. For instance, a Joint Agreement (kesepakatan bersama), following a meeting hosted by the Department of Religious Affairs and signed by the Vice-Governor, stipulated that while the ritual could be carried out on site, it should be carried out on a 'modest scale' (secara sederhana) and should not involve people from outside the island of Lombok. ${ }^{25}$

25 The meeting, organized by the Department of Religious Affairs on 3 November 2007, included members from the state-appointed Interreligious Harmony Forum (FKUB), representatives from Majelis Ulama Indonesia (MUI), several Muslim preachers and Islamic mass organizations. In addition to the organizing committee for the ritual, PHDI represented local Hindus. The provincial and district heads responsible for internal security (bakesbanglinmas) were also present. 
Moreover, local Hindus were advised to carry out the ritual in temples close to their place of residence rather than travelling to the contested site. The Joint Agreement was a compromise reached after lengthy discussion, as some participants had called for the ritual to be banned while the organizing committee and other Hindu representatives had underlined the grave spiritual danger of aborting a ritual that already was underway. The Joint Agreement referred to the destruction of equipment at the site and to escalating tensions. But rather than calling for efforts to bring the attackers to justice and safeguard those involved in the ritual, the meeting's 'solution' to this situation was to instruct Balinese Hindus to stay at home in order to prevent conflict.

Amphibi's statement, quoted earlier, appeared just a few days after the Joint Agreement had been signed, and its appearance caused much anxiety in Lombok Balinese circles. The statement made it clear that Amphibi not only opposed the Rinjani temple, but was prepared to send its troops (pasukan) to stop all religious activities at the site. Following its appearance, members of the committee organizing the purification ritual and officials from Parisada Hindu Dharma Indonesia (PHDI) were called to meet the Governor, Haji Lalu Serinata, who suggested that the best way to address the situation was to meet directly with the Amphibi leadership. ${ }^{26}$ The next evening five Balinese men travelled to the Amphibi headquarters in Jerowaru in south-east Lombok, where they met with TGH M. Sibawaihi Mutawalli. The head of the committee, Gdé Mandia, confided that he and the others had been rather nervous about this meeting. On learning about the purpose of the Karya Agung Bhuana Kertih ritual, the Amphibi leader, to Mandia's great surprise, responded that he had been misinformed about the aim of this ritual and personally promised to instruct all Amphibi branches to support its performance. This meeting was mentioned in an article in Suara NTB (20 November 2007), a newspaper popular on Lombok and Sumbawa, which quoted Gdé Mandia as saying that TGH M. Sibawaihi Mutawalli had stated, 'Provided that the ritual is not connected to the laying down of the first stone of the temple, then we [Amphibi] do not have any problems with

26 By this time, the tense situation contributed to worsen disagreements between those who wanted the ritual to be carried out in Kebaloan and those who favoured moving the ritual to a different location. Whereas the provincial chapter of PHDI favoured the latter solution, many Hindu priests represented by Peruman Pedanda NTB wanted the ritual to be carried out as originally planned. 
this ceremony.' The outcome of the interview also suggests that Amphibi's founder had a desire to re-establish friendly relations (silahturahmi) among Balinese and Sasak by clearing up such misunderstandings. Being keen to defuse tension, Gdé Mandia also used the opportunity to refute rumours connected to the controversial temple by stating, 'It is not true that the Hindu community wanted to build Asia's largest temple, we only wanted to build an ordinary (biasa biasa) one.'

However, the outcome of this informal meeting did not affect the decision to hold a provincial summit or Muspida (Musyawarah Pimpinan Daerah) to address the matter of the approaching ritual. As the highest decisionmaking body at province level, the Muspida comprises the head of police, the armed forces and representatives of the justice system, as well as heads of civil administration. ${ }^{27}$ The Muspida meeting ruled to disband the temple committee and to restrict the Karya Agung Bhuana Kertih ritual to only include those with religious responsibilities and residents from the Bayan district in northern Lombok, a decision ostensibly taken to safeguard 'interreligious harmony' (menjaga kerukunan hidup umat beragama) and maintain public order. By intervening directly in the ritual, the state effectively exercised what Agrama (2012:39) refers to as the 'active principle of secular power, which is the state's authority to decide what counts as religious and what scope it can have in social life'.

On learning of this ruling, many Balinese and other Hindus cancelled their plans to attend the Bhuana Kertih ritual. When priests and Hindus coming to worship approached the temple site, they encountered roadblocks and large numbers of armed Amphibi guards carrying out security checks. Most people were told that the ritual was 'illegal' and were turned away after having shown their identity papers and revealed their place of residence. Priests and people carrying offerings were also subjected to extensive security checks, but after some negotiation they were allowed to enter the site. The estimated 150 people who were allowed to enter were given tickets (karcis) to be shown when entering and exiting the temple area. This arrangement went on through the night and the 'operation' probably involved several Amphibi units. During the ritual, Amphibi truly 'acted like a state'. By issuing permits, regulating access and threatening

27 The Muspida meetings, an institution created during the New Order period, were expressions of the dual military-civilian form of administration of the New Order regime. 
those who failed to comply with their orders, the uniformed guards demonstrated Amphibi's sovereign power. Large numbers of police also guarded the site during the ritual, which served as an occasion for cooperation between official security and the informal security apparatus. Working alongside the police, the Amphibi guards probably felt confident that they defended Muslim as well as 'public' interest. The heavily guarded ritual, at which security personnel outnumbered the participants, made it appear as if Hindus constituted a major security threat. ${ }^{28}$

In January 2008, the outrage generated against the aborted Rinjani temple spilled over to another Hindu temple in a different part of Lombok. Located in Keru, a village with a mixed Sasak and Balinese population on the border of West and Central Lombok, Pura Sangkareang had recently been renovated and expanded (Telle forthcoming). As they prepared for the inauguration ceremony, a group of 22 Balinese men camped overnight in the temple. As they were about to go to sleep, the men were awakened by an advancing crowd of several hundred men. Yelling and hurling stones at the Balinese, who had no chance to escape, the mob hacked temple statues and carvings to pieces and torched several shrines. This attack was preceded by advance threats, and Balinese residents in Keru had asked the police for protection. While police officers did look into the situation, they failed to prevent the crowd from accessing the relatively isolated temple site. Though it is unclear who mobilized the sizable mob, the issues of a construction permit and funding sources for the renovations were used to provoke resentment. It was rumoured that the funds collected for the aborted Rinjani project had been diverted to finance the construction of the Sangkareang temple, and the fact that the existing temple had been renovated without a construction permit, was also used to fuel resentment. While the police and local government agencies did some investigation after this incident, the official response was to declare the temple site off limits. In effect, the official 'solution' has been to ban religious activities from taking place at the site rather than attempt to bring the attackers to justice or to assist in the rebuilding of the temple.

28 On November 23, the Lombok Post carried an article reporting that the ritual has been carried out safely and without disturbance. About 250 security personnel, including police, Brimob and intelligence units, guarded the ritual in which $15^{\circ}$ people had taken part. There was, however, no mention of why the ritual required massive security. 


\section{Conclusion}

The controversies surrounding these two Hindu temples illustrate a number of key political dynamics in contemporary Lombok. State officials, including the district heads and the governor, have relatively few political incentives to uphold (unpopular) minority interests. When controversial cases involving religious minorities arise, the need to avoid provoking sectarian violence easily becomes the rationale for denying minorities their constitutional rights, such as freedom of religion or belief. ${ }^{29}$ The kind of security-governance that has emerged on Lombok has some similarities to the way politics operated under the New Order regime, which turned a statist notion of security into a fundamental societal discourse (Bubandt 2005; Barker 2007). Compared with the repressive thrust of the Suharto regime, that recast many forms of popular mobilization as 'criminal' or 'subversive' threats to order and development, state officials in contemporary Lombok find it more difficult to demonize those who upset stability and order. After all, it is hard to deny that many violent confrontations in post-Suharto Lombok have been carried out by pamswakarsa groups that enjoy legitimacy and some degree of political backing (ICG 2003; MacDougall 2007; Kingsley 2012; Telle 2011).

In the cases I have sketched, we also see the contours of an emerging dynamic in which rumours, documents, intimidation and violence, combined with appeals to the law, are the central elements. Faith-based civilian security groups with conservative agendas raise issues by threatening violence. Creating issues and directing their allegations towards religious minorities or religious deviants, as in the case of Ahmadiyah adherents, faith-based security groups count on state officials to correct those who provoked their outrage in the first place. This 'conviviality' between thuggish gangs, state officials and the Department of Religious Affairs has pushed local politics in a xenophobic and authoritarian direction. Democratically elected politicians obstruct the legal process of granting permits and oppose projects that are likely to upset the religious sensibilities of their conservative or militant constituents. Bowing to the spectre of violence, they sacrifice the rights of minorities for the sake of stability and public order. At the same time, groups with violent reputations call on the government to take

29 The Constitution of Indonesia, Article 29(2) states that 'The state guarantees the right of all citizens to worship according to his or her own religion or belief.' 
action against those who fail to respect the law. For the time being, religious minorities are the losers in the bitter battles being played out around houses of worship.

\section{References}

Abrahams, Ray

2007 'Some thoughts on the comparative study of vigilantism', in: David Pratten and Abrams, Philip

Atreyee Sen (eds), Global vigilantes, pp. 419-42. London: Hurst Company.

1988 'Notes on the difficulty of studying the state', Journal of Historical Sociology Agamben, Giorgio $1-1: 58-89$.

$1998 \quad$ Homo sacer: Sovereign power and bare life. Stanford: Stanford University Press. Agrama, Hussein Ali

2012 Questioning secularism: Islam, sovereignty, and the rule of law in modern Allerton, Catherine Egypt. Chicago: University of Chicago Press.

2009 Introduction: Spiritual landscapes of Southeast Asia', Anthropological Forum 19-3:235-51.

Appadurai, Arjun

2006 Fear of small numbers: An essay on the geography of anger. Durham, NC and London: Duke University Press.

Aretxaga, Begoña

2003 'Maddening states', Annual Review of Anthropology 32-1:393-410.

Avonius, Leena L.

2004 Reforming Wetu Telu: Islam, adat and the promises of regionalism in post-New Order Lombok. [PhD thesis, University of Leiden.]

Barker, Joshua

1999 'Surveillance and territoriality in Bandung', in: Vicente L. Rafael (ed.), Figures of criminality in Indonesia, the Philippines, and colonial Vietnam, pp. 95-127. Ithaca, NY: Cornell Southeast Asia Program Publications. [Studies on Southeast Asia 25.]

2007 'Vigilantes and the state', in: Tony Day (ed.), Identifying with freedom: Indonesia after Suharto, pp. 87-94. New York and Oxford: Berghahn Books. [Critical Interventions 9.]

Beatty, Andrew

2012 'Kala defanged: Managing power in Java away from the centre', Bijdragen tot de Taal-, Land- en Volkenkunde 168-2/3:173-94.

Bubandt, Nils Ole

2005 'Vernacular security: The politics of feeling safe in global, national and local worlds', Security Dialogue 36-3:275-96.

2008 'Rumours, pamphlets, and the politics of paranoia in Indonesia', The Journal of Asian Studies 67:789-817. 
Budiwanti, Erni

$2009 \quad$ Pluralism collapses: A study of the Jamaa'ah Ahmadiyah Indonesia and its persecution. Singapore: National University of Singapore. [Asia Research Institute, Working Paper Series 117.]

Cederroth, Sven

1999 'From ancestor worship to monotheism: Politics of religion in Lombok', Temenos 32:7-36.

Comaroff, Jean and John L. Comaroff

2006 'Law and disorder in the postcolony, an introduction', in: Jean Comaroff and John L. Comaroff (eds), Law and order in the postcolony, pp. 1-56. Chicago: Crouch, Melissa A. University of Chicago Press.

2007 'Regulating places of worship in Indonesia: Upholding freedom of religion for religious minorities?', Singapore Journal of Legal Studies (July): 96-116.

2010 'Implementing the regulation on places of worship in Indonesia: new problems, local politics and court action', Asian Studies Review 34-4:403-19.

2012 'Law and religion in Indonesia: The constitutional court and the blasphemy law', Asian Journal of Contemporary Law 7-1:1-46.

Das, Veena and Deborah Poole

2004 'Introduction', in: Veena Das and Deborah Poole (eds), Anthropology in the margins of the state, pp. 2-32. Oxford: James Currey.

Day, Tony

2007 'Introduction: Identifying with freedom', in: Tony Day (ed.), Identifying with freedom: Indonesia after Suharto, pp. 1-18. New York and Oxford: Berghahn Books [Critical Interventions 9.]

Hadiz, Vedi

2010

Localizing power in post-authoritarian Indonesia: A Southeast Asian perspective. Stanford: Stanford University Press.

Hägerdal, Hans

$2001 \quad H i n d u$ rulers, Muslim subjects: Lombok and Bali in the seventeenth and eighteenth centuries. Bangkok: White Lotus Press.

Hansen, Thomas Blom and Finn Stepputat

2001 'Introduction', in: Thomas Blom Hansen and Finn Stepputat (eds), States of imagination: Ethnographic explorations of the postcolonial state, pp. 1-38. Durham, NC and London: Duke University Press.

2005 'Introduction', in: Thomas Blom Hansen, and Finn Stepputat (eds), Sovereign bodies: Citizens, migrants and states in the postcolonial world, pp. 1-36. Princeton, NJ: Princeton University Press.

Harnish, David D.

2006 Bridges to the ancestors: Music, myth, and cultural politics at an Indonesian festival. Honolulu: University of Hawaii Press.

Hauser-Schäublin, Brigitta

1997 Traces of gods and men: Temples and rituals as landmarks of social events and processes in a South Bali village. Berlin: Dietrich Reimer Verlag.

2011 'Spiritualized politics and the trademark of culture: Political actors and their use of adat and agama in post-Suharto Bali', in: Michel Picard and Rémy 
Madinier (eds), The politics of religion in Indonesia: Syncretism, orthodoxy, Hefner, Robert and religious contention in Java and Bali, pp. 192-213. London: Routledge.

$2000 \quad$ Civil Islam: Muslims and democratization in Indonesia. Princeton, NJ and Oxford: Princeton University Press.

Hull, Matthew S.

2012 Government of paper: The materiality of bureaucracy in urban Pakistan. Berkeley: University of California Press.

International Crisis Group (ICG)

2003 The perils of private security in Indonesia: Guards and militias on Bali and Kingsley, Jeremy J. Lombok. [Asia Country Report 67.]

2012 'Peacemakers or peace-breakers? Provincial elections and religious leadership in Lombok, Indonesia', Indonesia 93:53-82.

Kipp, Rita Smith and Susan Rodgers

1987 'Introduction: Indonesian religions in society', in: Rita Smith Kipp and Susan Rodgers (eds), Indonesian religions in transition, pp. 1-31. Tucson: The University of Arizona Press.

Klinken, Gerry van and Joshua Barker

2009 'Introduction: State in society in Indonesia', in: Gerry van Klinken and Joshua Barker (eds), State of authority: The state in society in Indonesia, pp. 1-16. IthKristiansen, Stein aca, NY: Cornell Southeast Asia Program. [Studies on Southeast Asia 50.]

2003 'Violent youth groups in Indonesia: The cases of Yogyakarta and Nusa Tenggara Barat', Soujourn 18-1:110-38.

Lindsey, Tim

2001

'The criminal state: Premanisme and the new Indonesia', in: Grayson J. Lloyd and Shannon L. Smith (eds), Indonesia today: Challenges of history, pp. 283Lund, Christian 97. Lanham, MD: Rowman \& Littlefield.

2006 'Twilight institutions: Public authority and local politics in Africa', Development and Change 37-4:685-705.

MacDougall, John M.

2007 'Criminality and the political economy of security in Lombok', in: Henk Schulte Nordholt and Gerry van Klinken (eds), Renegotiating boundaries: Local politics in post-Suharto Indonesia, pp. 281-306. Leiden: KITLV Press.

Mbembe, Achille

$2001 \quad$ On the postcolony. Berkeley: University of California Press.

McVey, Ruth

1995 'Shaping the Sasak: Religion and hierarchy on an Indonesian Island', in: B. Werlen and S. Wölty (eds), Kulturen und Raum, pp. 311-31. Zurich: Röegger.

Migdal, Joel S.

$2001 \quad$ State in society: Studying how states and societies transform and constitute one another. Cambridge: Cambridge University Press.

Olle, John 2009

'The Majelis Ulama Indonesia versus "heresy": The resurgence of authoritarian Islam', in: Gerry van Klinken and Joshua Barker (eds), State of authority: 
The state in society in Indonesia, pp. 95-116. Ithaca, NY: Cornell Southeast Asia Program. [Studies on Southeast Asia 50.]

Picard, Michel

2011 'From Agama Hindu Bali to Agama Hindu and back: Toward a relocalization of the Balinese religion?' in: Michel Picard and Rémy Madinier (eds), The politics of religion in Indonesia: Syncretism, orthodoxy, and religious contention in Java and Bali, pp. 117-41. London: Routledge.

Ramstedt, Martin (ed.)

$2004 \quad H i n d u i s m$ in modern Indonesia: A minority religion between local, national, and global interests. London: RoutledgeCurzon. [RoutledgeCurzon-IIAS Asian Studies Series.]

Ropi, Ismatu

2007 'Regulating worship,' Inside Indonesia 89, Jan-March.

Schmitt, Carl

1976 The concept of the political. New Brunswick, NJ: Rutgers University Press. [Orig. 1932.]

Schulte Nordholt, Henk

2002 'A genealogy of violence', in: Freek Colombijn and J. Thomas Lindblad (eds), Roots of violence in Indonesia: Contemporary violence in historical perspective, pp. 32-61. Leiden: KITLV Press.

2007 Bali: An open fortress 1995-2005: Regional autonomy, electoral democracy and entrenched identities. Singapore: National University of Singapore Press.

Scott, James C.

1998 Seeing like a state: How certain schemes to improve the human condition have failed. New Haven, CT: Yale University Press.

Sen, Atreyee and David Pratten

2007 'Global vigilantes: Perspectives on justice and violence', in: David Pratten and Atreyee Sen (eds), Global vigilantes, pp. 1-24 London: Hurst Company.

Siegel, James T.

1998 A new criminal type in Jakarta: Counter-revolution today. Durham, NC: Duke

Sidel, John T.

2006 Riots, pogroms, jihad: Religious violence in Indonesia. Ithaca, NY and London: Cornell University Press.

Spyer, Patricia

2006 'Some notes on disorder in the Indonesian postcolony', in: Jean Comaroff and John L. Comaroff (eds), Law and disorder in the postcolony, pp. 188-218. Chicago: University of Chicago Press.

Telle, Kari

2009a

'Dharma power: Searching for security in post-New Order Indonesia', Social Analysis 53:141-56.

2009b 'Swearing innocence: Performing justice and 'reconciliation' in post-New Order Lombok', in: Birgit Bräuchler (ed.), Reconciling Indonesia: Grassroots agency for peace, pp. 57-76. London: Routledge.

2009c 'Spirited places and ritual dynamics among Sasak Muslims on Lombok', Anthropological Forum 19-3:289-306. 
2010 'Seduced by security: The politics of (in)security on Lombok, Indonesia', in: John-Andrew McNeish and Jon Harald Sande Lie (eds), Security and development, pp. 130-42. New York and Oxford: Berghahn Books [Critical Interventions 11.]

2011 'Spirited warriors: Conspiracy and protection on Lombok', in: Kirsten W. Endres and Andrea Lauser (eds), Engaging the spirit world: Popular beliefs and practices in modern Southeast Asia, pp. 42-61. New York and Oxford: Berghahn Books.

(forthcoming) 'Changing spiritual landscapes and religious politics on Lombok', in: Brigitta Hauser-Schäublin and David D. Harnish (eds), Religious trajectories in majority-minority relationships in Bali and Lombok. Leiden: Brill.

Thomas, Philip

1998 'Conspicuous construction: Houses, consumption and relocalization in Manambondro, Southeast Madagascar', Journal of the Royal Anthropological Institute 4-3:425-46.

Zurbuchen, Mary S. (ed.)

2005 Beginning to remember: The past in the Indonesian present. Singapore: Singapore University Press.

Wilson, Ian Douglas

2009 "As long as it's halal": Islamic preman in Jakarta', in: Greg Fealey and Sally White (eds), Expressing Islam: Religious life and politics in Indonesia, pp. 192210. Singapore: ISEAS.

2010 'The rise and fall of political gangsters in Indonesian democracy', in: Edward Aspinall and Marcus Mietzner (eds), Problems of democratisation in Indonesia: Elections, institutions and society, pp. 199-218. Singapore: ISEAS.

2012 'Testing the boundaries of the state: Gangs, militias, vigilantes and violent entrepreneurs in Southeast Asia', in: Richard Robison (ed.), Routledge handbook of Southeast Asian politics, pp. 288-301. London and New York: Routledge.

Wæver, Ole

1995

'Securitzation and desecuritization', in: Ronnie D. Lipschutz (ed.), On security, pp. 46-86. New York: Columbia University Press. 